\title{
10
}

\section{Homelands as outstations of public policy}

Kingsley Palmer

This chapter is about the rise and fall of outstations in Aboriginal Australia. In the 1970s, governments, both State and Federal, were at first enthusiastic about these settlements, encouraged by an ideology that promoted outstations as beneficial - in terms of health, social well-being, cultural maintenance and the preservation of links to country, which were generally recognised as being of singular importance for Aboriginal Australians. But funding outstations proved to be expensive, and progressively, funding responsibility was devolved to the States, which in turn showed a developing reluctance to spend money on often isolated and costly support services. Moreover, as ideologies shifted, outstations were seen as too often wasteful of scarce resources and generally did not provide much needed health services. Training and employment - seen by many as the way forward for Indigenous Australians - were conspicuously absent from most outstations.

This chapter tells something of the history of program support for outstations by reference to both a national evaluation of funding for outstations and a case study drawn from the author's own fieldwork. The future of outstations as settlements for Australia's Indigenous people is uncertain since governments are unable (or unwilling) to justify the considerable expense involved. However, there are 
indications that Aboriginal Australians in some circumstances are diverting their own resources to facilitate choice in their place and mode of residence, although this is an option available to only a privileged few.

\section{Homelands and outstations}

Aboriginal Australia in the 1970s saw an unprecedented shift from centralised community living to what has been labelled 'decentralisation'-a process particularly apparent in remoter parts of the continent. Decentralisation was typified by a return to the country with which participant groups had a traditional affiliation. It was a movement away from larger communities that were under the control of the Australian Government or church missions. The newly established settlements were commonly called 'outstations' or sometimes 'homelands' in acknowledgement of the autochthonal relationship between residents and the country of the new settlement. The movement was noted by many commentators and anthropologists at the time (for example, Gray 1977; Coombs et al. 1982). But it was a change in living arrangements that was part of other factors too-in particular, the advent of legislated land rights for Indigenous Australians (Peterson 1982) and an advance in the policy of self-determination for Australia's Aboriginal people. In stark contrast with past practice, Indigenous Australians could live where they chose and have some opportunity to determine their own way forward.

The outstation movement was much vaunted as a solution to the many ills that dogged the administration of public policy in relation to Australia's Indigenous minority. Apart from the social justice issues and recognition of rights for native peoples - part of a wider movement in postcolonial administrations across the globe - outstations were praised as offering better health, living conditions and social harmony than the crowded and sometimes dysfunctional settlements where alcohol and substance abuse were regularly endemic. The Federal Government was prepared to fund these arrangements (Coombs et al. 1982: 428-30). While some voiced reservations about the policy (Coombs et al. 1982: 430), overall the outlook was optimistic. Outstations represented a significant paradigm shift in the administration of Aboriginal affairs. It was a bold new endeavour that only required that funding be provided by the Federal Government to make it a success. 


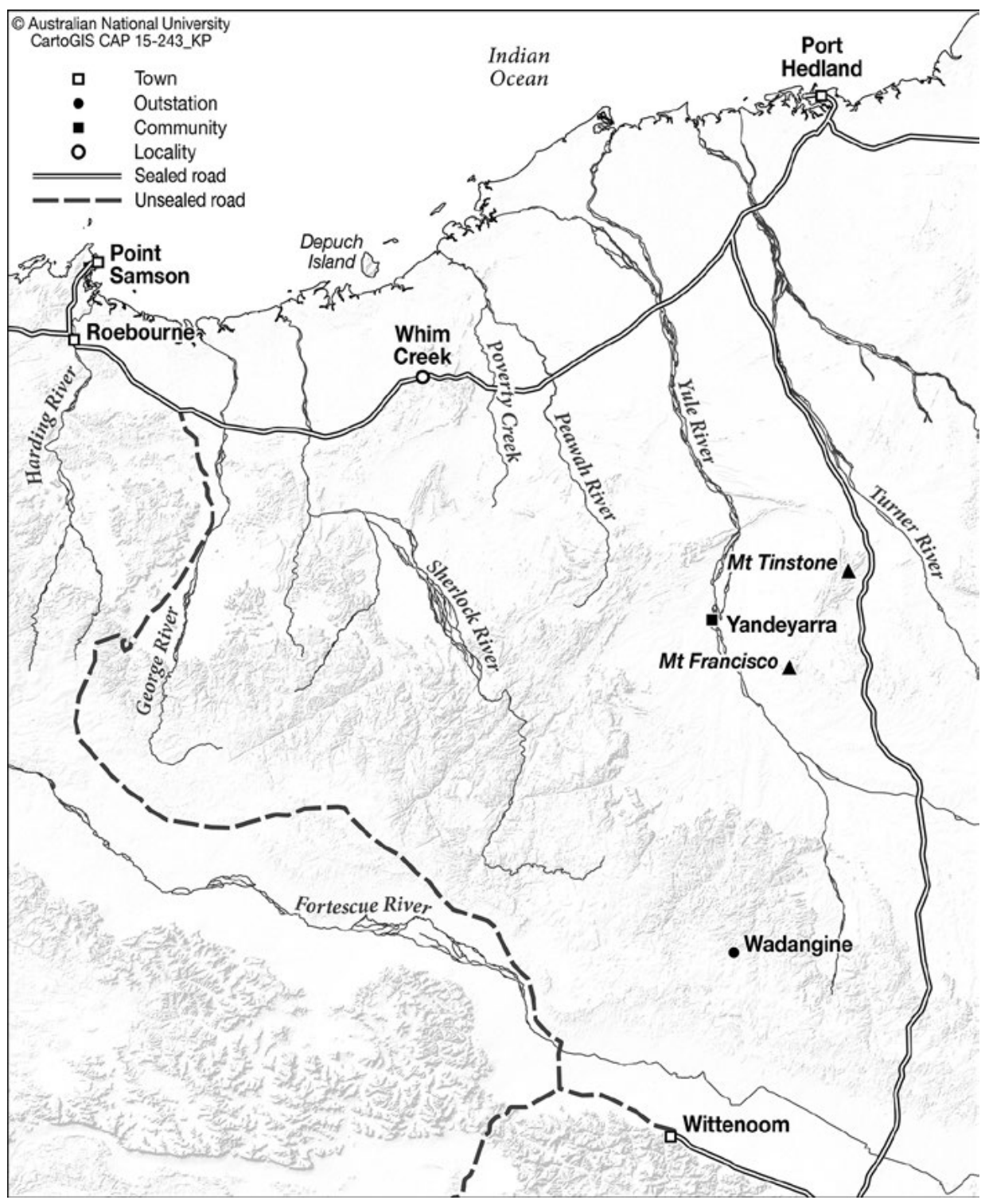

Map 10.1 Wadangine in relation to Yandeyarra.

Source: Karina Pelling, CartoGIS, ANU College of Asia and the Pacific

What might be termed the golden era of outstations was to be short-lived. By the mid-1990s, there were serious problems emerging with the decentralisation process. Health care was difficult to deliver to many outstations while other services like education and training were either impractical to offer or were prohibitively expensive. Transport and provision of power, safe drinking water and sanitation added to the host of difficulties that were intrinsic to maintaining 
multiple small communities in out-of-the-way places with no real employment opportunities and limited economic possibilities. There were allegations of waste, assets unused, and houses never occupied.

Here I review some data that was developed in the context of a review of outstations across Australia in 1998. Commissioned by the now defunct Aboriginal and Torres Strait Islander Commission (ATSIC), the review sought to provide data that would alleviate problems of perceived waste in resource centres and the outstations they serviced. Such an endeavour was consistent with an increase in funding restraints, a desire to mainstream and demands for greater public accountability. It was, however, also tempered by an ideology that saw outstations as examples of self-determination, independence and a return to the land, supported by the commissioners who allocated funding. With the benefit of hindsight, it is now possible to see that such aspirations were doomed, particularly once ATSIC was abolished. One reading of these materials is to understand the homelands movement and its supporting bureaucracy in the late 1990s as itself an outstation of public policy.

\section{Wadangine, 1972 and 2013}

Wadangine is an outstation approximately $40 \mathrm{~km}$ south-south-east of Yandeearra (Yandeyarra), an Aboriginal community in the Pilbara region of Western Australia. I first visited Wadangine in 1972 on a familiarisation trip as part of an introduction to my work in the Pilbara region for the Western Australian Museum. At this time, Wadangine was a working cattle camp - always known as 'The Outcamp' rather than an outstation, in the cattlemen's parlance of the time. Over the next few years, Yandeearra, which had been subject to much neglect, was re-established as a community and Wadangine became the bush camp for the cattle business where a few families lived and worked. The majority of those associated with the group with whom I worked lived at Yandeearra, which was progressively developed as a community.

Over my many years of association with Yandeearra, I saw the settlement at Wadangine develop slowly. It offered limited facilities: a makeshift shelter that functioned as a workshop and only one house. Most people who chose to live there occupied small tin sheds or camped under tarps or other makeshift shelters. Despite these limitations, residents of both Yandeearra and Wadangine were marked by their resilience, self-reliance and desire for self-determination. The residents had engaged in a radical struggle that had seen them strike for better wages and conditions in 1946 on the pastoral properties in the region that 
provided their main employment. Many left the white-owned cattle stations to set up their own enterprises, including mining, shelling and feral goat shooting as well as the Yandeearra pastoral business.

Wadangine was not then an outstation in the sense often applied to places where people have moved away from a central settlement to live on their own country. Most Yandeearra residents (but by no means all) were immigrants to the area, with their country further to the east in the desert regions beyond the De Grey River. Wadangine was not then for most residents a 'homeland'. However, in terms of self-determination, Wadangine was an expression of the desire of its residents to live on country, generate an income through employment and have as complete a management of their own affairs as was possible, given the funding constraints and bureaucratic requirements that went with them.

\section{Returning to country}

Outstations and 'outcamps' of the sort I came to know at Wadangine have a long and complex history in the administration of Indigenous affairs in Australia. In public policy terms, they were regarded as positive arrangements that might alleviate all manner of social and economic ills.

Apart from the strong desire of Aboriginal people to return to traditional land to meet their responsibilities in relation to their land, the [outstation] movement has also been a reaction to the stresses of living in settlements, reserves and missions and to the practice of bringing diverse groups of Aboriginals together to live in these artificial communities. There was widespread dissatisfaction with the institutionalised nature of settlements and missions and a recognition that they had huge social problems ... By contrast, outstation life offered a return to a 'healthy social and physical environment' away from the tensions and trouble associated with large communities and mixed groups. (Blanchard 1987: 14)

The Report of the House of Representatives Standing Committee on Aboriginal Affairs of March 1987, Return to Country: The Aboriginal Homelands Movement in Australia (Blanchard 1987), gave formal recognition of the importance of outstations in remote Australia. In fact, the political will to advance the cause of outstations was already well established. The Standing Committee itself identified that there was an urgent need for 'a detailed investigation' into homelands (Blanchard 1987: xxxi) and invited the minister to refer to it an inquiry into homeland centres. The terms of reference for the inquiry were very broad as the committee was asked to report on ' $[t]$ he social and economic circumstances of Aboriginal people living in homeland centres or outstations, and the development of policies and programs to meet their future needs' (Blanchard 1987: xxxi). 
The inquiry received 44 written submissions comprising more than 2,100 pages of evidence. It examined 111 witnesses at public hearings held around the nation, the transcripts comprising 1,250 pages. The inquiry also considered 17 exhibits and visited approximately 70 communities or settlements (Blanchard 1987: xxxi-xxxii, Appendices 1-4). The 58 recommendations were directed to the then Minister for Aboriginal Affairs, Clyde Holding. The conclusions, recommendations and the arguments for them were the most authoritative expression of the pro-outstation wisdom of the time and were highly influential in framing both the Department of Aboriginal Affairs' and subsequently ATSIC's programs as they related to rural and remote community development.

The 'Blanchard Report', as it was called after the chairman of the committee, made its 58 recommendations with the clear intention of improving the economic security and viability of outstations and increasing the level of services available to outstation residents. At this time the future of outstations was secure: the committee recognised the contribution outstations had in furthering the aspirations of Indigenous Australians and in improving their quality of life.

Before 2004 outstations were sustained by funding, for the most part through the agency of ATSIC, which had programs devoted to outstation resource delivery and housing. Typically, outstations were serviced by small organisations based in a parent community known as an Outstation Resource Centre (ORA). These centres received funding based on the requirements of the outstations they looked after. Broadly, funding for outstations was channelled through ATSIC's State and regional offices to the ORAs, which had responsibility for allocating funds to the outstations for which they were responsible and provided services. The funds were deployed under the auspices of the Community Housing and Infrastructure Program (CHIP) and the Community Development Employment Projects (CDEP) scheme. Other sources of funding from within ATSIC were generally small and specific to a particular activity such as arts or cultural activities. Other Federal Government department programs were also represented, but actual amounts of money varied enormously. Some agencies received funding from State or Territory bodies and government programs, but again absolute amounts varied greatly and grants were often of short-term duration (Altman et al. 1998: 3.1-3.4). ATSIC was responsible for the majority of the funds allocated and ATSIC and its CHIP and CDEP programs facilitated the development and perpetuation of outstations. Outstations were, then, in this environment 'viable', but of course only for as long as the ATSIC (or other) funding continued.

While this funding environment reflected the persistence of the conventional ideology that underpinned the Blanchard Report, by the late 1990s within what was already a somewhat beleaguered bureaucracy, the question of outstation funding and the economic wisdom of the programs had already been subject to 
substantial criticism. This resulted from cited instances of waste, often noted by Liberal politicians, with tales of generators left to rust in remote locations in their unopened crates, solar panels stolen by passers-by and new houses erected in places where no one had ever lived. Those of us who visited numerous outstations in the course of several national and regional reviews can attest to these stories. However, there were other examples of thriving communities and well-managed resources. Plans to review resource centre funding to make them more accountable and to implement management techniques (regional outstation policy, strategic plans, performance indicators, formula funding) were all steps to stem the waste and make the system more efficient and effective. It was hoped thereby to secure the elements of the program that many Aboriginal people as well as non-Indigenous employees in communities and resource agencies considered to be a sustainable and positive alternative to living in larger communities with their attendant antisocial behaviour, drinking, drugs and alienating living conditions. However, by the time ATSIC commissioned a national review in 1997, the cost of funding outstations, the criticisms of their ability to advance the economic situation of Aboriginal people and accompanying lack of political will meant that the situation was probably beyond redemption for at least many of the outstation resource centres.

\section{The 1997 review}

The review proposed by ATSIC in 1997 canvassed a wide-ranging agenda that was to include definitional issues, funding levels, accountability as well as the governance and structures of the ORAs themselves. It also asked for a strategy for the future and an implementation timetable. The consultancy was managed by a consortium of three parties from the Australian Institute of Aboriginal and Torres Strait Islander Studies (myself), the Centre for Aboriginal Economic Policy Research (Jon Altman) and a private company, Tallagalla Consultants (Dan Gillespie). Additional researchers were David Martin, Bill Arthur, Richard Davis, Jerry Schwab and Diana Hafner. These researchers came from an anthropological background and many had extensive experience working in remote Aboriginal Australia while some had hands-on experience working at outstations and with ORAs. It was a strong team.

The review was based on field studies of 25 ORAs. ${ }^{1}$ Subsequently, one ORA in Queensland was found to have only marginal involvement in servicing outstations so was excluded from the survey results. We estimated that the six

1 South Australia = three; Queensland = five; Northern Territory = 12; and Western Australia = five 
researchers spent more than 100 days in the field so it was an empirically based study that used a mixture of questionnaires and a field observation manual to guide researchers as to the issues that required attention.

The review was not focused on the specifics of the 24 case studies and the many outstations they represented. It was designed to provide an overview of the national situation. In this regard some statistics are significant as they provide an indication of the state of outstations during the last half of the 1990s.

We claimed that the review represented 'the most comprehensive survey of ORAs undertaken to date' (Altman et al. 1998: 6.13). ATSIC data provided to us suggested that at the time of the review there were approximately 12,000 Indigenous Australians living at about 1,000 outstations serviced by approximately 100 ATSIC-funded ORAs. Assuming that the ATSIC figures were correct and that our sample was broadly representative, the review sampled about 25 per cent of ORAs Australia-wide. The 24 ORAs the review visited serviced 340 outstations, indicating that there were possibly 1,400 outstations in Australia (Altman et al. 1998: 6.14-6.15) — somewhat more than the official ATSIC figures. We estimated the populations of the outstations and projected them to provide Australia-wide figures, using a range of population figures from maxima to minima, median and 'effective', which took into account the period an outstation might be vacant. These data are shown in Table 10.1.

Table 10.1 Some estimates of outstation populations at 24 ORAs and Australia-wide, 1997

\begin{tabular}{|l|r|r|}
\hline & Sampled ORAs & Australia-wide \\
\hline Minimum population & 3,381 & 13,524 \\
\hline Maximum population & 8,129 & 32,516 \\
\hline Usual population & 5,770 & 23,080 \\
\hline Effective population & 4,893 & 19,572 \\
\hline
\end{tabular}

The survey also reported on the numbers of houses, vehicles and funding, which I have extracted for interest in Table 10.2.

Table 10.2 Some estimates of outstation costs and resources, 1997

\begin{tabular}{|l|l|l|}
\hline Item & Total in survey & Total across Australia \\
\hline Houses & 964 & 'Several thousand'; \$200 m minimum \\
\hline Vehicles & 196 & 800 \\
\hline Budget & $\$ 54 \mathrm{~m}$ & $\$ 200 \mathrm{~m}$ \\
\hline CDEP contribution & $\$ 24 \mathrm{~m}$ & $25-39 \%$ of total CDEP channelled via ORAs \\
\hline
\end{tabular}


The ORAs ranged in size from those that serviced just three outstations to those that had responsibility for 44. Budgets showed enormous variation, ranging from as low as $\$ 140,000$ per annum to a high of $\$ 11.5$ million. Sources of funding were variable, with CDEP and the ATSIC-administered CHIP providing the bulk of funds. Outstation populations ranged from two to 770 and staff of the ORAs from 0.5 to 39 .

Gaining reliable figures was complex, particularly with respect to outstation populations, which generally showed great variation. Figures were developed through a sophisticated set of measures that attempted to take into account fluctuation and gain some idea of what might be the 'usual' population. The range of the organisations reviewed and the implications this had for similar bodies across Australia made generalising hazardous.

One example of the data retrieved is shown in Table 10.3, which shows not only the range of funding and numbers of outstations for each ORA, but also the average calculated costs of outstations in each case. It is notable that while the average cost per outstation was a little more than $\$ 23,000$, the median cost was more than $\$ 56,000$. It is apparent from this that there was a huge variation in costs.

Figures for per capita expenditure were equally diverse. The review found that there was an average of $\$ 4,462$ per capita but a median of $\$ 2,547$. Some per capita figures were as high as $\$ 15,000$, while others fell below the $\$ 1,000$ mark.

The use of assets, particularly houses, which represented for the most part the most expensive infrastructure on outstations, was subject to review, although statistical data in this regard proved difficult to present as reliable. We concluded:

Generally, the standard of housing was well below that expected of public or private housing. In some cases, houses are little better than tin sheds, unlined, with no windows and inadequate services or no services at all. (Altman et al. 1998: 5.46)

Table 10.3 Agency funding, outstation numbers and average costs per outstation, 1997

\begin{tabular}{|l|r|r|r|}
\hline No. & Funding & O/s nos & Annual cost \\
\hline 1 & $\$ 1,712,000$ & 30 & $\$ 57,067$ \\
\hline 2 & $\$ 2,500,000$ & 10 & $\$ 250,000$ \\
\hline 3 & $\$ 465,000$ & 13 & $\$ 35,769$ \\
\hline 4 & $\$ 413,476$ & 44 & $\$ 9,397$ \\
\hline 5 & $\$ 285,086$ & 3 & $\$ 95,029$ \\
\hline 6 & $\$ 445,258$ & 19 & $\$ 23,435$ \\
\hline
\end{tabular}




\begin{tabular}{|c|c|c|c|}
\hline No. & Funding & O/s nos & Annual cost \\
\hline 7 & $\$ 138,000$ & 7 & $\$ 19,714$ \\
\hline 8 & $\$ 156,471$ & 14 & $\$ 11,177$ \\
\hline 9 & $\$ 238,105$ & 19 & $\$ 12,532$ \\
\hline 10 & $\$ 497,213$ & 16 & $\$ 31,076$ \\
\hline 11 & $\$ 281,420$ & 12 & $\$ 23,452$ \\
\hline 12 & $\$ 108,014$ & 6 & $\$ 18,002$ \\
\hline 13 & $\$ 193,933$ & 20 & $\$ 9,697$ \\
\hline 14 & $\$ 154,058$ & 9 & $\$ 17,118$ \\
\hline 15 & $\$ 1,192,000$ & 23 & $\$ 51,826$ \\
\hline 16 & $\$ 1,953,546$ & 11 & $\$ 177,595$ \\
\hline 17 & $\$ 1,282,000$ & 7 & $\$ 183,143$ \\
\hline 18 & $\$ 883,770$ & 20 & $\$ 44,189$ \\
\hline 19 & $\$ 1,836,779$ & 11 & $\$ 166,980$ \\
\hline 20 & $\$ 70,000$ & 3 & $\$ 23,333$ \\
\hline 21 & $\$ 441,621$ & 6 & $\$ 73,604$ \\
\hline 22 & $\$ 198,000$ & 14 & $\$ 14,143$ \\
\hline 23 & $\$ 70,000$ & 7 & $\$ 10,000$ \\
\hline 24 & $\$ 70,000$ & 16 & $\$ 4,375$ \\
\hline Average & $\$ 649,406$ & 14.17 & $\$ 56,777$ \\
\hline Median & $\$ 349,281$ & 12.50 & $\$ 23,443$ \\
\hline Range & $\$ 2,430,000$ & 41.00 & $\$ 245,625$ \\
\hline
\end{tabular}

We also reported:

Overall, house vacancy rates are, at least in some areas, substantial. However, it should be borne in mind that some dwellings classified as houses are uninhabitable by wider community standards. Nevertheless, there is a general view, supported by the data collected, that vacant houses, some representing a substantial investment of money, are a problem in that substantial resources and infrastructure are under-utilised or, in extreme cases, wasted. Houses on vacant outstations are often subject to vandalism and the Review noted many instances of theft of equipment like stoves and solar panels. (Altman et al. 1998: 5.48)

In a sample of 14 ORAs, the range of unoccupied houses at outstations was 0 per cent (one case) to 91 per cent (one case). The median rate of unoccupied houses was 45 per cent and the mean 33 per cent (Altman et al. 1998: Appendix 5, p. 189). It is evident from these figures that a substantial proportion of housesexpensive assets on outstations - were either not utilised or underutilised. 
Home ownership was not considered in the review, as it would have been, for the majority of outstation residents, well beyond their economic means. However, we did suggest that rental agreements might assist in stemming waste, which was clearly evident in the comments we made.

Discussion of cost recovery and user pays was circumspect. We reported:

It is evident that the introduction of a partial user pays system may go some way toward rebutting myths that Indigenous Australians are entirely welfare dependent. However, if the source of the payment is itself a welfare benefit, then it is hard to understand the logic that drives this reasoning, unless the partial user pays system is designed to be somehow educative. (Altman et al. 1998: 5.33)

The limitations of the cost-recovery process in a community of people who are, for the most part, highly welfare dependent and poor must be understood from the outset. Concerns were expressed about the capacity of some to meet the costs of services, and agencies need to have the flexibility to administer costrecovery processes to ensure that economic hardship is not a direct consequence (Altman et al. 1998: 5.35).

We ended the review by stressing that it was our opinion that outstations were likely to endure and rather than diminish might in time increase in numbers and importance:

Indeed there is likelihood that in the native title era, outstation populations will expand. Outstations are a valid lifestyle choice for Indigenous people, especially those who are owners of considerable tracts of land in rural and remote parts of Australia. (Altman et al. 1998: 6.3)

We also stated that there were longer-term cost benefits:

The longer-term costs and benefits to government of outstations: While it is very difficult to quantify the net cost/benefits of outstations, there seems little doubt that rigorous costing, taking into account documented cultural, economic and health benefits, would indicate a positive net benefit. (Altman et al. 1998: 6.7)

\section{Post-review policy}

While it is tempting to assume that the report of the outstation review languished on dusty bookshelves in the offices of ATSIC in Canberra, there is evidence that some of the recommendations were implemented - or attempts were made to do so. For example, the recommendations of the review relating to setting funding for individual outstations against national benchmarks, population and geographic variables such as distance and access from the ORA (Altman et al. 1998: Recommendations 1, 12 and 13, p. 18) were implemented 
by at least one regional council. Two of us (Palmer and Gillespie) went on to undertake reviews of several regional councils and their outstations in an attempt to establish policy directions through the development of homeland policies, plans and procedures, which was another recommendation of the review (Altman et al. 1998: Recommendation 17, p. 19). These plans included the development of funding formulae that could be used in relation to each outstation managed by an ORA, designed to bring a greater level of accountability and uniformity to the funding and management mix.

The development of these plans and funding tools was a positive step. It perhaps helped to make the process more equitable and the system more efficient. However, the fundamentals of the problems raised by outstations for policymakers, politicians and bureaucrats remained unresolved. Outstations were expensive places to run, tended by their nature to highlight waste and could generally not provide health care, some essential services, training and employment - all of which were seen by many as essential for the social and economic betterment of Indigenous Australians.

\section{Endemic problems}

The recommendations of the review were made on the assumption that ATSIC funding would continue - or at least be replaced with a similar arrangement. There was then a prophetic ring to the following, which warned against a loss of federal funding:

There are growing trends to mainstreaming in Indigenous affairs in particular, and prospects of greater fiscal devolution to the States, partly associated with the proposed division of GST revenue, in general. This indicates that the Federal Government and ATSIC will need to ensure diligently that mainline departments and State/Territory governments meet their obligations to outstation residents as Australian citizens. The data presented in this Review on relative State/Territory contributions to ORAs do not augur well in this regard. (Altman et al. 1998: 6.10)

There are three issues raised in the review that are of particular relevance to this prospect of a changed policy environment. The first is the outstation population. It was not that most outstations were not used-although some were certainly vacant. Our data (see Table 10.1) showed that there was a very large range in outstation populations (approximately 13,500 to 32,500 nationally). The implication of these data was that outstation residents also lived in places other than their outstation, and most likely at the parent community. One inference to be drawn from this is that the services and facilities of the outstation replicated in whole or in part those provided in the parent community. At the time of the review, this duplication of expenditure on essential services, shops, 
health, education and infrastructure was not a matter for inquiry. However, the 'part-time' characterisation of many outstations - notably, represented by the house vacancies - made the funding vulnerable on the grounds that in a fiscal environment where there was a lack of financial resources, duplication could not be afforded.

The second issue of note relates to the failure of the system to recover costs or implement cost recovery. The outstation review was, I think, realistic in identifying the practical problems evident in this regard since outstation residents lacked the capacity to pay. Moreover, since funds flowing to outstation residents were almost exclusively some form of welfare payment (including CDEP), we questioned the benefits of collecting by way of user payment from what amounted to a subsistence income. Figures on cost recovery reflected a disinclination to follow this path (Altman et al. 1998: Appendix 5, p. 191). The 24 ORAs in the study raised only 2.33 per cent of their annual budget through cost recovery (Altman et al. 1998: Table 'Summary of Data', Appendix 2). Outstations were by this account a fully subsidised welfare benefit vulnerable to the criticism that they were a luxury that the Indigenous budget could ill afford.

There is a third factor, which we did flag in our report: the move towards mainstreaming. There was a growing view that economic futures lay with centralised communities where there might be some possibility of meaningful employment and training. Given demands for uniform and acceptable service provision, health care and education, outstations were again vulnerable to those who saw them as retarding economic development and maintaining unacceptable levels of impoverishment and denial of basic services.

\section{Leaving the country?}

Since 2004 there has been a major shift in both State and Federal policies regarding the funding of outstations. John Howard announced ATSIC's abolition on 15 April 2004, saying that 'the experiment in elected representation for indigenous people has been a failure' (SMH 2004). On 28 May 2004, the Howard Government introduced legislation into the Federal Parliament to abolish the commission. After a delay, the Bill finally passed both houses of Parliament in 2005. ATSIC was formally abolished at midnight on 24 March 2005. ${ }^{2}$ In 2007 the Federal Government transferred outstation funding for the Northern Territory to the NT Government and ceased direct funding of outstations, ending a 20-year commitment to support homelands following the Blanchard review

2 en.wikipedia.org/wiki/Aboriginal_and_Torres_Strait_Islander_Commission (accessed 17 April 2015). 
(Altman et al. 2008: 9). This followed the NT Emergency Response intervention of June 2007, which gave the Commonwealth powers to intervene in the affairs of Indigenous Territorians at a level, according to one commentator, 'unmatched by any other policy declaration in Aboriginal affairs in the last forty years' (Hinkson 2007: 1). While the 'Intervention', as it became known, did not directly target outstations, it set administrative arrangements in place that would facilitate the further development and control of larger communities or hubs for the provision of all services, rather than encouraging peripheral development in remote homelands and the aspirations for self-determination that had accompanied such endeavours. ${ }^{3}$

While ATSIC provided policy direction, the ideology that lent principal support to outstations outweighed these vulnerabilities and inherent weaknesses. The outstation review I have discussed above was reporting on a system that was sustained by ideology engendered by ATSIC, which was probably at the time of the review already doomed. ATSIC policy was itself an outstation of mainstream government policy and, as subsequent events have shown, doomed to suffer a withering death to most of its parts. Indeed not only did the funding through ATSIC cease because of the organisation's demise, but also Federal funding for outstations was not a part of the new arrangements, while State and Territory governments provided minimal funds in this regard. Funding for housing and infrastructure was mainstreamed or directed towards building houses in centralised communities, not, as had been the case with the CHIP, in a manner that was designed to assist outstations. At the same time, the Federal Government started winding back the CDEP scheme, which was transferred in 2004 to the Commonwealth Department of Employment and Workplace Relations, rendering it less accessible and sympathetic to the needs of outstation residents (Saunders 2004: 6). Without the funding, many of the outstations we reviewed ceased to be financially viable and the resource centres were either closed or struggled to stay afloat by seeking funding from elsewhere.

While much may have changed since Blanchard, it would appear that for some politicians at least, elements of the ATSIC ideology remain intact. The Northern Territory Indigenous MLA Alison Anderson's policy statement on homelands of February 2013 (Anderson 2013) rings with the rhetoric of times gone by. This rhetoric is part of the ideology that holds that outstations are, echoing Blanchard, 'a good thing' - usually for reasons of cultural continuity and attachment to country and perhaps too because it is asserted that they provide for better health outcomes. The data to support such statements are notoriously

3 The 2007 Memorandum of Understanding between the Australian and Northern Territory Governments on Indigenous Housing, Accommodation and Related Services precluded the Northern Territory from constructing new housing on outstations with the funds the Commonwealth provided under the Memorandum. (Indigenous Affairs Forum of the NT n.d.: 1.) 
hard to find, and the political will to expend funds proportionately lacking. Anderson tells us that in the Territory today there are 10,000 people living on homelands, representing some 25 per cent of the remote Indigenous population of the Northern Territory. She reports that there are 2,400 dwellings on 520 homelands (Anderson 2013). She asserts:

Our spiritual connection to the land is unique, and today I seek to explain that and to celebrate it, and to describe what this government proposes to do to maintain it through the homelands.

But our indigenous connection is a matter of history, deep history. It goes back well over 40,000 years. Even those of us who have accepted Christianity still feel that connection intensely; it is part of who we are. How we go about keeping that connection alive is crucial to our wellbeing, and homelands are vital to that. They are our ancestral places, where through ceremonies and other means we can fulfil our obligations to our inherited country and its Law. They are safe places where we feel secure, places where we can achieve physical and spiritual health.

We're aware it could be more expensive to have people living in hundreds of small communities scattered around the Territory than restricted to a few dozen towns. But the benefits are potentially great, benefits in health and wellbeing and social harmony. So on behalf of the government, I reaffirm the integral role of the homelands in the Territory. I commit us to providing the residents of the homelands with the same services as other Territorians, within reason and accepting that in many cases they are starting from a low base. (Anderson 2013)

Anderson, then, recognises that homelands are expensive, a cost she considers to be offset by the benefits to health, well-being and social harmony. Services will be provided to the same standard as those available to other Territorians, 'within reason' - a limitation that is not defined. Anderson tackles a principal problem with the implementation of this policy (lack of funding for houses) by suggesting that home ownership is the answer, and this comprises much of the thrust of her policy. Although the NT Government committed to spend some money on infrastructure on outstations, Altman (2012) has noted that in per capita terms this does not amount to very much. While the thrust of Anderson's statement is encouraging to those who support outstation development and sustainability, it remains unclear how services and housing will actually be provided and to what extent. ${ }^{4}$

4 Alison Anderson resigned from the Country Liberal Party (CLP) in 2014 and became an independent briefly before joining the Palmer United Party (PUP). She resigned from the PUP in November 2014 and rejoined the CLP in February 2015. (en.wikipedia.org/wiki/Alison_Anderson; accessed 21 April 2015). 
The reality of the situation now with respect to outstations is expressed in a paper prepared by the Indigenous Affairs Forum of the Northern Territory, which cites the Council of Australian Governments' (COAG) National Partnership Agreement on Remote Service Delivery, which speaks of 'investment decisions' rather than funding and specifically has it that:

$[P]$ riority for enhanced infrastructure support and service provision should be to larger and more economically sustainable communities where secure land tenure exists, allowing for services outreach to and access by smaller surrounding communities, including:

- recognising Indigenous peoples' cultural connections to homelands (whether on a visiting or permanent basis) but avoiding expectations of major investment in service provision where there are few economic or educational opportunities; and

- facilitating voluntary mobility by individuals and families to areas where better education and job opportunities exist, with higher standards of services. (COAG 2008: A-1)

In short, investment must be economically viable to be condoned.

The other major policy principle outlined in the forum's paper is that housing and provision of basic services are a State or Territory responsibility. The paper states that the 'Australian Government recognises the cultural, environmental and strategic importance of homelands across Australia as well as the importance of homelands for their linguistic diversity and Indigenous Knowledge and is committed to sustaining this diversity and knowledge' (Indigenous Affairs Forum of the NT n.d.: 1). However, paying for this asset is not contemplated. It remains, then, an ideal rather than a prospective reality.

More recently (in December 2014), the conservative Barnett Government in Western Australia announced that it would cease funding 150 remote communities in that State because it lacked the funds to do so. The Monthly reported that Premier Colin Barnett had stated that 'his state can't afford to keep the outstation communities going, because the money he received from the feds to do so isn't enough' (Marks 2014).

\section{Wadangine revisited}

My visit to Wadangine in 2013 highlighted for me the rise and fall of outstations. I observed during this visit that there were signs of a time where the facilities lacking in the early 1970s had been provided: additional housing, reticulated water, power and toilet blocks. However, these were now defunct or unserviceable and I was told that no one lived at Wadangine, although several 
families would like to do so but could not for the lack of basic facilities. Moreover, no one knew whom to ask or where to go to seek these things. I suspect this is because there is in fact nowhere to go. Yandeearra, the parent community, is planning (so I am told) additional houses and upgraded facilities because it is regarded as a focal community or a 'hub'. However, my brief discussions with the community manager at Yandeearra led me to the conclusion that servicing Wadangine was not on his agenda. Expenditure is to be directed to a community where at least some basic services can be concentrated, building on existing infrastructure and services that are already provided: a school, a visiting clinic, a swimming pool and reasonable road access.

\section{An end to outstation dependency}

The rhetoric continues to ring in the political and ideological prose of those who wish to advocate outstations as providing a better way of life and a solution to many of the social ills that we observe all too often on our travels round Indigenous communities and on the edges of remote towns. However, outstations as public policy have long had funding implications that make them unattractive to planners and bureaucrats and difficult for politicians to balance against the other many competing demands of their electorates. This is, of course, no new phenomenon. The outstation review I have outlined above shows dramatically that the outstation system as we reported on it was flawed in its administration by imbalance, inequities and high costs. While it may have been possible to argue that these costs were offset against the social benefits, these advantages could never be properly documented. Moreover, the prevailing ethic of mainstreaming and centralising Australia's Indigenous minorities so that they could be provided with conventional services (at whatever cost) seemed, I think, more appealing and achievable than funding the outstation program.

I hold that not all is doom and gloom in this regard. While I find Alison Anderson's account of outstations in the Northern Territory overly optimistic and the policy statement fenced with qualifications, I am aware from my travels that individual small communities continue to exist. Generally, residents or bureaucrats do not describe these small communities as 'outstations' because they are not part of a national or regional program that advocates the homeland ideal. Rather they survive on the little funding that can be found from one-off grants for such things as Indigenous business enterprise, environmental protection or the private contributions of their residents. In resource-rich areas, people may choose to allocate their royalty payments or other funds to maintaining an outstation. I have come across some settlements (former outstations) that are sustained solely by the income of the residents, often derived through full-time employment in neighbouring towns. Such arrangements are limited 
and highly dependent on the dedication, ability and resources of one or two principal players. In my experience, Australia's Indigenous minority continues to vote with their feet. It is a matter of regret, given the undoubted benefits of outstation living compared with those of urban fringe camps and suburban ghettos, that for most moving to an outstation (or what was an outstation) and sustaining a life there are well beyond their financial reach.

\section{References}

Altman, J. 2012. Another decade for homelands policy debacle. Tracker (May): 22-3.

Altman, J., Gillespie, D. and Palmer, K. 1998. National Review of Resource Agencies Servicing Indigenous Communities, 1998. Canberra: Aboriginal and Torres Strait Islander Commission.

Altman, J., Kerins, S., Fogarty, B. and Webb, K. 2008. Why the Northern Territory Government needs to support outstations/homelands in the Aboriginal Northern Territory and national interest. CAEPR Topical Issue No. 17/2008. Canberra: Centre for Aboriginal Policy Research.

Anderson, A. 2013. Homelands/outstation policy. Ministerial Statement. NT Legislative Assembly, Darwin. www.alisonanderson.com.au/ministerialstatement-homelandsoutstations-policy (accessed 5 December 2013).

Blanchard, C. A. 1987. Return to Country: The Aboriginal Homelands Movement in Australia. Report of the House of Representatives Standing Committee on Aboriginal Affairs. Canberra: Commonwealth of Australia.

Coombs, H. C., Dexter, B. G. and Hiatt, L. R. 1982. The outstation movement in Aboriginal Australia. In E. Leacock and R. Lee (eds), Politics and History in Band Societies. Cambridge: Cambridge University Press, pp. 427-40.

Council of Australian Governments (COAG) 2008. National Partnership Agreement on Remote Service Delivery. Canberra: COAG.

Gray, W. J. 1977. Decentralisation trends in Arnhem Land. In R. M. Berndt (ed.), Aborigines and Change: Australia in the '70s. Canberra: Australian Institute of Aboriginal Studies, pp. 114-23.

Hinkson, M. 2007. Introduction: In the name of the child. In J. Altman and M. Hinkson (eds), Coercive Reconciliation: Stabilise, Normalise, Exit Aboriginal Australia. Melbourne: Arena Publications, pp. 1-12. 
Indigenous Affairs Forum of the Northern Territory n.d. Outstations/homelands discussion paper. Status of Australian Government Outstations/Homelands Policy and Current Principles for Investment. Canberra: Department of Families, Community Services and Indigenous Affairs.

Marks, R. 2014. Gathering storm: The assault on self-determination in the West. [Blog]. The Monthly, 4 December. www.themonthly.com.au/blog/russellmarks/2014/04/2014/1417667971/gathering-storm (accessed 17 April 2015).

Peterson, N. 1982. Aboriginal land rights in the Northern Territory of Australia. In E. Leacock and R. Lee (eds), Politics and History in Band Societies. Cambridge: Cambridge University Press, pp. 441-62.

Saunders, W. 2004. Indigenous centres in the policy margins: The CDEP scheme over 30 years. Paper for the ACOSS Annual Congress 2004, Alice Springs, NT.

Sydney Morning Herald (SMH) 2004. Clark vows to fight as ATSIC scrapped. Sydney Morning Herald, 15 April. www.smh.com.au/articles/ 2004/04/15/1081998279884.html (accessed 18 January 2012). 
This text is taken from Experiments in self-determination: Histories of the outstation movement in Australia, edited by Nicolas Peterson and Fred Myers, published 2016 by ANU Press, The Australian National University, Canberra, Australia. 